DOI: $10.33766 / 2524-0323.90 .90-102$

УДК 343.5

А. О. Ведернікова,

ад'юнкт Луганського державного

університету внутрішніх справ

імені Е. О. Дідоренка

(м. Сєвєродонецьк, Україна)

e-mail: Annavedernikova1989@gmail.com

iDhttps://orcid.org/0000-0002-4526-1277

\title{
АМЕРИКАНСЬКИЙ ДОСВІД КРИМІНАЛЬНО-ПРАВОВОГО РЕГУЛЮВАННЯ БУЛІНГУ
}

Проблема насиљства в навчальних закладах існує в багатьох країнах світу, але не всі протидіють зазначеному явищу і проводять відповідну антибулінгову політику. Америка - одна 3 країн, яка активно бореться з булінгом у школі, i iї досвід $є$ важливим для України. У статті проаналізовано статистичні показники виявів булінгу та кібербулінгу в США. Висвітлено особливості антибулінгової політики різних штатів США, наведено загальні положення, визначено сучасні тенденції та перепони в боротьбі зі цькуванням. Запропоновано імплементацію окремих положень у національне законодавство.

Ключові слова: булінг, цькування, дискримінація, антибулінгове законодавство США, антибулінгова політика, кібербулінг, харасмент, нульова толерантність.

Постановка проблеми. Із метою забезпечення реалізації прав дитини на життя, здоров'я, освіту та з огляду на світові суспільні течії, 18 грудня 2018 року було прийнято Закон України «Про внесення змін до деяких законодавчих актів України щодо протидії булінгу (цькуванню)». Вищезазначеним законом сформульовано визначення булінгу та внесені зміни до Кодексу України про адміністративні правопорушення, де передбачено адміністративну відповідальність за цькування в закладах освіти. Запобігання цькуванням у школі є предметом законодавчого регулювання в зарубіжних країнах. Оцінка такого досвіду є важливою для юридичної науки, оскільки дослідження булінгу в науковій літературі здійснюються здебільшого фахівцями з педагогіки, соціології та психології. Дослідження досить тривалого законодавчого досвіду інших держав щодо протидії булінгу, зокрема США, допомагає зрозуміти рівень проблеми й можливі перспективи нормативного регулювання. Досвід США цікавий тим, що в кожному штаті підхід до боротьби зі цькуванням у школах дещо різниться, і це дозволяє проаналізувати різні підходи в боротьбі з булінгом. Законодавчо регулюються й інші форми булінгу, зокрема й кібербулінг, коли цькування здійснюється із застосуванням засобів електронних комунікацій. Під час дослідження було виявлено низку позитивних чинників правового регулювання булінгу в США, які можуть бути імплементовані в українське законодавство.

Аналіз останніх досліджень і публікацій. У соціологічній, психологічній та педагогічній літературі проблема булінгу знайшла висвітлення в працях вітчизняних (Г. В. Коваль, Г. О. Алєксєєнко, Ю. Б. Брочковська, С. С. Стельмах, І. А. Гайдамашко , О. О. Шуміло, Н. В. Лесько та ін.) та зарубіжних учених (С. M. Arora, V. Besag, H. Leymann, R. Hazler, Kvak, C. Lee, K. Rigby, E. Roland, P. T. Slee та ін.). Однак найбільш грунтовні напрацювання щодо булінгу належать D. Olweus. 3 правової точки

(C) Ведернікова А. О., 2020 
зору булінг досліджували такі зарубіжні вчені, як: S. Hinduja, J. W. Patchin, S. Ćmiel, S.Kmiotek, B. High, J. Kuczynski, L. L. Finley тощо. У вітчизняній юридичній науці ця проблематика не достатньо висвітлена, проте окремі дослідження мають Т. Миськевич, І. Г. Лубенець, А. О. Жеброва, Т. В. Миронюк. Отже, подальша правова оцінка булінгу є перспективним напрямом досліджень.

Формулювання цілей. Мета дослідження - з'ясувати особливості кримінально-правового регулювання булінгу в США, що становить інформаційно-аналітичну основу для розробки ефективних заходів запобігання зазначеному явищу на національному рівні.

Виклад основного матеріалу. Національний центр статистики освіти США за підтримки Міністерства освіти провели шкільне опитування директорів щодо злочинності та безпеки в 2017 - 2018 навчальному році. Так 27,9 \% середніх шкіл повідомили про знущання з учнів, які відбувалися принаймні раз на тиждень; водночас серед старших школярів цей відсоток складає 15,8 \%, а серед початкових шкіл - 8,7 \%. Про те, що кібербулінг трапляється в школі хоча б один раз на тиждень, частішеповідомляють середні та старші школи (33, 1 \% та 30,2 \% відповідно), ніж початкові (4,5\%) [1]. За їхньою інформацією, булінг та кібербулінг у США білыше виявляється в середній школі невеликих міст з кількістю учнів понад одну тисячу, особливо на Заході та Середньому Заході країни. Проте це латентна злочинність й оприлюднюються не всі факти цькування. Тому можна вважати, що вказані показники є заниженими.

Національний центр статистики освіти США та Бюро статистики Міністерства юстищії США в останньому оприлюдненому звіті національного опитування учнів віком від 12 до 18 років середньої та старшої шкіл державних та приватних навчальних закладів США щодо обстеження злочинності та безпеки за 2016 - 2017 навчальний рік зазначають, що з 24650000 респондентів 20,2 \% повідомили, що в школі їх цькують. Серед чоловіків цей показник складає 16,7 \%, серед жінок - 23,8 \%. У 6-му класі зазнають булінгу 29,5 \% учнів, у 7-му - 24,4 \%, у 8-му - 25,3 \%, у 9-му - 19,3 \%, у 10 му - 18,9 \%, в 11-му - 14,7 \%, у 12-му - 12,2 \% [2]. Отже, із дорослішанням кількість знущань зменшується. Усього булінгу зазнавали 4986000 респондентів, із них: відчували глузування й образи 64,4 \%; щодо 66,2 \% розпускалися чутки; 19,2 \% отримували погрози щодо завдання їм шкоди; штовхали, робили підніжки або плювали на 26,1 \% учнів; примушували до певних дій 9,3 \%; вилучали з колективу 25,5 \%; знищувалося майно в $7 \%$ жертв булінгу [3]. Із дорослішанням булери переходять в інтернет-площину. Кібербулінг частіше здійснюють старшокланики (19\%), ніж учні середньої школи (12 \%), а його жертвами втричі частіше стають жінки, ніж чоловіки (21 \% проти 7 \%). Булінг із використанням інформаційних технологій є більш небезпечним через можливі репости та анонімність правопорушника, яка надає йому відчуття безкарності. Тому більш високі показники повідомлення про будь-які негативні наслідки (63 \%) мають учні, які зазнали кібербулінгу порівняно з тими, 3 кого знущалися лише особисто (37 \%). Перші повідомили про систематичні випадки уникнення місць активності в школі (29 \%) порівняно з тими, які повідомили про особисте знущання (19\%). Окрім того, учні, які зазнали кібербулінгу, частіше прогулюють заняття в школі (13 \% проти 3 \%). Однак, білышість учнів (56\%) повідомляють дорослим саме про кібербулінг, ніж про особисте цькування (45 \%) [4], а це зменшує його латентність і надає можливість залагодити проблему та притягнути винного до відповідальності. Cyberbullying Research Center у 2019 році провів опитування 4972 школярів віком 
12-17 років щодо проявів булінгу та кібербулінгу в навчальних закладах США та порівняв їхні результати з результатами 2016 року. У 2019 році білыше половини (52,3 \%) учнів зазначили, що вони зазнавали знущань у школі за останні 30 днів, порівняно 3 38,6 \% у 2016 році (на 35 \% білые). Окрім того, майже третина (30,4 \%) учнів зазначила, що вони знущалися з інших у школі впродовж останнього місяця 2019 року порівняно 3 11,4 \% у 2016 році. Не було різнищі в кількості учнів, які зазнавали знущань у школі протягом життя (73,1 \% проти 72,8 \%), але кількість респондентів, які повідомили, що пригнічували інших хоча б раз у житті, зросла до 40,7 \% 331 \%. Зазначені показники булінгу в США зображені нижче в діаграмі 1 [5].

Імовірніше, такий приріст показників відбувся через зменшення латентності булінгу. У США діє велика кількість освітніх програм щодо протидії булінгу, тому учні більше усвідомлюють проблему шкільних знущань та їхніх наслідків. Підлітки відчувають ефективність програм протидії булінгу і повідомляють про цькування, у такий спосіб зазначаючи перспективні напрями для подалышої профілактичної роботи. Збільшення кількості учнів, які сказали, що вони знущаються з інших у школі, може бути проявом для усвідомлення протиправних дій та їхніх наслідків. Тобто знущань не стає білье, а школярі починають розуміти, що штовхання, образи, глузування, вигнання з колективу тощо - це не жарт, а прояви булінгу.

За інформацією Cyberbullying Research Center, відсоток школярів, які заявили, що вони зазнали кібербулінгу з 2016 по 2019 рік, трохи збілышився. Так у 2019 році 17,4 \% школярів зазнавали кібербулінгу за попередні 30 днів порівняно 3 16,5 \% у 2016 році. У 2019 році здійснювали кібербулінг за попередні 30 днів 6,3 \% школярів порівняно з 5,6 \% у 2016 році. Також відбулося збільшення кількості школярів, які коли-небудь піддавалися кібербулінгу (з 33,6 \% до 36,5 \%) або самі вчиняли кібербулінг протягом свого життя (з 11,4 \% до 14,8 \%). Зазначені показники кібербулінгу в США зображені в діаграмі 1 [5]. І лише 22 \% жертв кібержорстокого поводження будуть проводити дії проти хулігана [6].

Жоден федеральний закон США безпосередньо не стосується булінгу; у деяких випадках знущання ототожнюється із дискримінацією, коли воно грунтується на національному походженні, расі, кольорі шкіри, віці, статі, інвалідності

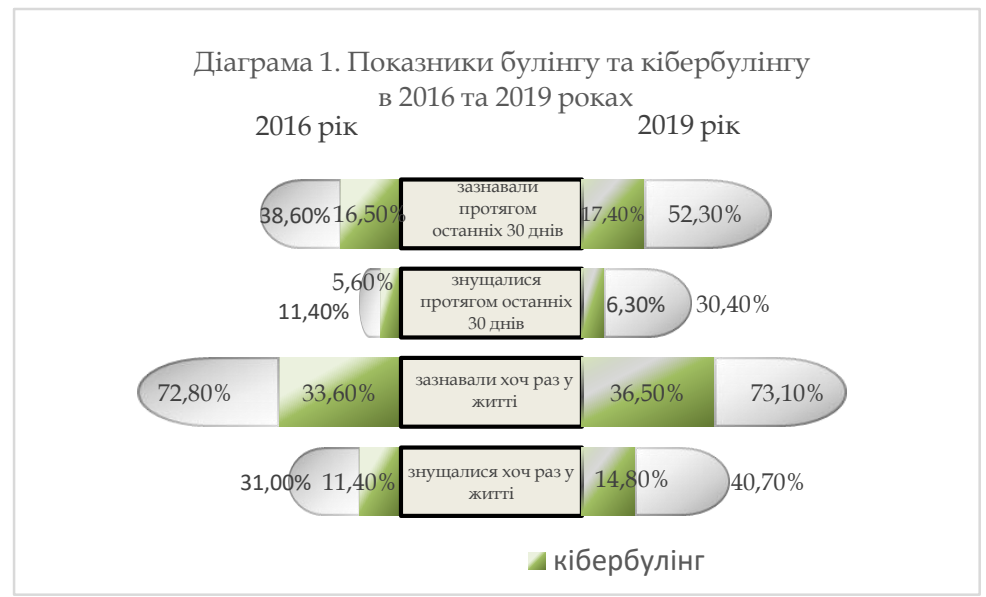


чи релігії. Коли цькування пов'язані із дискримінацією, то школи, що фінансуються федеральною владою, зобов'язані розв'язувати ці питання в адміністративному порядку. Якщо ситуація не буде вирішена належним чином, можуть втручатися Управління цивільних прав Міністерства освіти США та Відділ цивільних прав Міністерства юстиції США. Більшість судових справ розглядається згідно 3 цивільним законодавством. Компенсація шкоди, завданої булінгом, покладається на людину, яка вчинила це правопорушення, або на школи чи органи керівництва закладу освіти. Навчальні заклади є відповідальними за добробут учнів. Окрім того, у всіх штатах США є різні кримінальні закони, які зазначають відповідальність за окремі прояви насильства, а саме заподіяння тілесних ушкоджень, напад, побиття, переслідування, домагання, сексуальне насильство, сексинг, грумінг, хейзинг, хулінганство, «злочини ненависті».

У 2018 році американські науковці Sameer Hinduja й Justin W. Patchin проаналізували кримінально-правове законодавство США щодо протидії кібербулінгу та дійшли висновку, що: у 48 штатах ухвалені закони, які мають положення про кібербулінг або інтернет-домагання; 44 штати передбачають кримінальні санкції за електронне цькування; 49 штатів застосовують шкільну антибулінгову політику, а 45 штатів передбачають шкільні санкції за вказані правопорушення; у 17 з них відповідальність настає за дії, вчинені поза межами навчального закладу [7]. У всіх штатах $є$ закони щодо протидії булінгу, і більшість з них містить чіткі посилання на електронні форми. Першим штатом, який ухвалив антибулінговий закон, була Джорджія (1999 рік). Останнім - Монтана, у 2015 році.

Оцінку якості та дієвості чинних законів, а також зміни до них, здійснює Громадська спостережна організація «Bully Police USA». Усі штати, які не мають закону, автоматично отримують оцінку «F». Оцінка «D» надається штатам із недієвими законами, «С» - посередніми законами, «В» - прийнятними законами та «A» - тим, хто має «майже ідеальні» закони. Якщо закони містять положення про кібербулінг та забезпечують консультування жертв булінгу, їм надають додатково «+». Отже, після започаткування поняття булінгу в законі 2015 року «Montana Code Annotated Title 20. Education Chapter 5. Pupils. Part 2. Duties - Prohibitions - Penalties» оцінка штату підвищилась 3 «F» до «B +». Штати постійно доповнюють свої антибулінгові закони різними положеннями, у такий спосіб підвищуючи рейтинг. Наприклад, у 2005 році Меріленд ухвалив закон «НВ 407», який був оцінений на «С +» за системою оцінювання Bully Police. У 2008 році було схвалено оновлений закон «НВ 199», який оцінено вже на «А ++». У 1999 році штат Джорджія ухвалив закон «HB 84, гл. 282 (OCGA § 20-2-751.4 та OCGA § 20-2-751.5.)», наголосивши на важливості навчання персоналу методам запобігання булінгу та насильницьким діям щодо однокласників, отримавши оцінку «С». У 2010 році штат ухвалив закон «SB 250», яким були внесені зміни до «Chapter 2 of Title 20 of the Official Code of Georgia Annotated», отримавши оцінку «A ++».

Щоб мати найвищу оцінку, закон повинен бути ефективним і відповідати таким вимогам:

1. Має використовуватися термін «булінг», а не «злочини ненависті», домагання, дискримінація чи залякування.

2. Повинен бути правозахисним і захищати права окремого студента та його особисту безпеку, а не акцентувати увагу на безпеці шкільних будівель. 
3. Мусить бути визначення булінгу та харасменту (з англійської «harassment» - домагання), тому що визначення проблеми є запорукою вирішення іi. Не має бути особливого акценту на визначенні жертв, бо всіх дітей, які зазнають булінгу, потрібно захищати.

4. Повинен містити рекомендації, інструкції щодо зразкової антибулінгової політики, реалізації проєкту, програми, закону протидії булінгу.

5. Має передбачити освіту фахівців усіх рівнів, починаючи з Управління державного нагляду з питань освіти та закінчуючи шкільними округами, закладами освіти, батьками та учнями. Разом вони можуть визначати та встановлювати правила, політику та знаходити й реалізовувати чинні програми проти знущань.

6. Програми проти булінгу мусять мати зобов' язальний, а не рекомендаційний характер.

7. Повинен містити дату, до якої має бути встановлена антибулінгова політика та граничний термін іï реалізації.

8. Має містити положення щодо захисту учнів від помсти, переслідування за звернення щодо проявів цькування або помилкового звинувачення в булінгу.

9. Має надавати гарантії проти судового позиву для шкільного округу за належне виконання антибулінгової політики. За поведінку булерів відповідають його батьки, якщо вони не докладуть жодних зусиль, щоб зупинити їхню дитину після повідомлення про знущання.

10. Повинен призначати консультації для жертв, які роками страждають після жорстокого насильства, отримання допомоги завдяки програмам із розширення можливостей, терапії, консультування або оплачуваних медичних витрат.

11. Має нести підзвітність законотворцям або Державному управлінню 3 питань освіти, передбачення наслідків для навчальних закладів або шкільних округів, які не дотримуються закону. Обов'язково розміщувати у вільному доступі чи повідомляти учнів та батьків про антибулінгову політику й процедури звітування.

12. Повинні бути положення про кібербулінг [8].

Наразі 13 штатів мають оцінку «А ++» (Делавер, Флорида, Джорджія, Кентуккі, Массачусетс, Маріленд, Мічиган, Північна Дакота, Нью-Гемпшир, Нью-Джеpci, Техас, Вірджинія, Вайомінг), п'ять штатів - «А +» (Айдахо, Род-Айленд, Вашингтон, Західна Вірджинія), три штати - «А» (Аляска, Огайо, Оклахома), десять штатів - «А -» (Аркансаз, Айова, Іллінойс, Індіана, Мейн, Міссурі, Південна Кароліна, Теннессі, Юта, Вермонт). Оцінку «В +» мають вісім штатів (Алабама, НьюМексико, Невада, Нью-Йорк, Пенсильванія, Південна Дакота, Північна Кароліна, Вісконсин), «В» мають три штати (Каліфорнія, Колорадо, Канзас), «В -» - чотири штати (Арізона, Коннектикут, Гаваї, Монтана). Оцінку «С +» має Небраска, «С»Micciciпi, Луїзіана, «C -» -Міннесота. Тобто 31 штат містить закони, які Bully Police USA оцінює, як «майже ідеальні», 15 штатів - статус «прийнятних», а лише чотири штати мають «посередні» антибулінгові закони.

Як зазначено на урядовому сайті США (stopbullying.gov) [9], антибулінгові закони мусять мати загальні ключові компоненти, які перетинаються з вимогами «Bully Police USA» щодо необхідності надання заяви про мету прийняття акту; визначення булінгу та кібербулінгу; вимог районної політики; звітності; гарантій та підтримки жертв булінгу; навчання персоналу; сповіщення щодо антибулінгової політики. Окрім того, закони мусять мати чітку область застосування (наприклад, 
на шкільних ділянках, у спонсорських навчальних заходах, на шкільному транспорті тощо); визначену процедуру розслідування; ступінчастий спектр наслідків та санкщій; зобов' язання регулярно аналізувати та оновлювати антибулінгову політику; заохочення впровадження програм профілактики булінгу; залучення батьків. Пропонується наводити невичерпний перелік характеристик учнів, які історично були об'єктами знущань, що суперечить вимогам «Bully Police USA». Проте не в усіх штатах ураховані вищевказані складові антибулінгового законодавства.

Найліпшим антибулінговим законом, за версією організації «Bully Police USA», є закон штату Флорида «Закон Джефрі Джонстона про боротьбу за всіх студентів», який забороняє знущання над будь-яким студентом або співробітником закладу освіти та має конкретні посилання на булінг та кібербулінг. Булінг означає систематичне та хронічне заподіяння фізичного поранення чи психологічного катування одному чи декільком студентам та містить таке: дражніння; соціальне відчуження; погрози; залякування; переслідування; фізичне насильство; крадіжку; сексуальні, релігійні чи расові домагання; публічне або приватне приниження; знищення майна. Окрім того, вищевказаний закон дає визначення кібербулінгу та такому його виду, як харасмент. Закон не передбачає кримінальних санкцій за такі діяння, але спрямовує шкільні округи на розробку антибулінгової політики та повідомлення про випадки знущань. Кожен шкільний округ схвалює та переглядає щонайменше кожні три роки антибулінгову політику, яка забороняє булінг та харасмент стосовно учня чи працівника громадського навчального закладу. Шкільний округ під час прийняття та перегляду антибулінгової політики залучає учнів, батьків, учителів, адміністраторів, шкільних працівників, волонтерів шкіл, представників громад та місцевих правоохоронних органів. Закон передбачає обов'язковий перелік положень, які повинна містити антибулінгова політика кожного навчального закладу. До першого січня кожного року Уповноважений з питань освіти звітує перед губернатором штату Флорида, президентом Сенату та спікером Палати представників про виконання вимог «Закону Джефрі Джонстона про боротьбу за всіх студентів». Від належного виконання шкільними закладами всіх умов, передбачених вищевказаними законом, залежить розподіл коштів, що надаються шкільному округу [10].

Штат Нью-Джерсі в 2002 році схвалив закон «АВ 1874», який було оновлено в 2010 році. Він також оцінений на «А ++» та вимагає, щоб кожен шкільний округ схвалював політику, яка забороняє домагання, залякування чи булінг на території, яка є шкільною, під час виконання шкільних функцій або в шкільному автобусі. Політика повинна фіксувати визначення поведінки, яка вважається булінгом, наслідки для участі в такій поведінці, порядок розслідування повідомлень про зазначену поведінку, виклад положень про заборону помсти або розправи щодо осіб, які повідомляють про булінг, та наслідки для неправдивого звинувачення. Вимагає від працівників школи, учнів чи добровольців повідомляти про будь-які випадки домагань, залякування та булінгу відповідним шкільним посадовцям. Надає імунітет від будь-яких позовів щодо збитків, які виникають унаслідок неможливості виправити інцидент особам, які повідомляють про ці випадки [11]. Антибулінгова політика цього штату направлена на профілактику знущань у закладах освіти. Наприклад, одна програма Нью-Джерсі відправляє учнів середньої та вищої 
школи, які демонструють ризики жорстокого поводження, проходити п' ятиденну позашкільну навчально-реабілітаційну програму [12, с. 290].

Наприклад, у Каліфорнійському кодексі про освіту розкривається визначення булінгу, а також чітко прописані всі можливі його прояви з використанням засобів зв' язку. Окрім поняття «кібербулінг», законодавець вводить поняття «кіберсексуального булінгу». Акт кіберсексуального насильства означає розповсюдження, підбурювання чи підбурювання до розповсюдження фотографії чи іншого візуального запису учня іншим учнем чи шкільним персоналом за допомогою засобів електронних комунікацій. Він має або обгрунтовано може мати один або декілька таких наслідків: знаходження сумлінного учня чи учнів у страху заподіяння йому шкоди або його майну; спричинення сумлінного учня відчутно згубного впливу на його фізичне або психічне здоров'я; спричинення відчутного втручання в успішність сумлінного учня; спричинення відчутного втручання в здатність сумлінного учня брати участь у послугах, заходах чи привілеях, наданих школою або користуватися ними. Перелічені наслідки є загальними для всіх виявів булінгу. Фотографія чи інший візуальний запис, має містити зображення оголеної, напівголої або сексуально відвертої фотографії або іншого візуального запису неповнолітньої особи, яку можна ідентифікувати з фотографії, візуального запису чи інших електронних дій. Особливістю цього закону є те, що передання або розміщення в інтернеті неналежної інформації не вважається розповсюдженою поведінкою, тобто не дає системності [13]. Використання електронного пристрою зв'язку для того, щоб викликати побоювання за своє життя, обвинувачується як проступок, який караєтъся до одного року в'язнищі та/або штрафом до 1000 доларів [14]. Зазначений закон оцінений організащією Bully Police USA на «В». Ще не вистачає визначення «харасмент», захисту від репресій, помсти або неправдивого звинувачення та захисту шкільного округу від судових позовів щодо дотримання політики [15].

У штаті Міссурі кібербулінг визначається Статутом Міссурі як знущання, через передавання зв'язку, що має, але не обмежується повідомленнями, текстом, звуком або зображенням за допомогою електронного пристрою, зокрема телефону, бездротового телефону або іншого пристрою бездротового зв'язку, комп'ютера або пейджера тощо [16]. Працівники школи зобов' язані повідомляти про будь-які відомі випадки знущань. Особа, яка використовує соціальні медіа для знущань з іншої особи, зокрема, із застосуванням жорстоких погроз, може бути звинувачена в домаганнях (харасменті), проступку класу А, але це стає злочином класу D, якщо потерпілому 17 років чи менше (а відповідачу 21 рік або більше), або якщо відповідач має попереднє засудження щодо домагань [14]. Організащія Bully Police USA зазначає, що закон має лише декілька абзаців, але він добре написаний та охоплює достатню частину системи їхнього оцінювання, для того щоб відповідати оцінщі «А -». У ньому відсутні деякі важливі чинники, такі як: захист від судових позовів, допомога жертвам чи булерам, а також вимоги до програм проти знущань [17].

На сьогодні не існує послідовних висновків щодо змісту політики проти булінгу та поширеності цькування. Ordonez у 2006 році виявив, що менш глибинними були політики й програми в боротьбі проти булінгу в школах, діяльність яких пов'язана з більш високими темпами фізичної та словесної віктимізації учнів. Такі вчені, як Woods i Wolke, у 2003 році та Gower, Cousin та Borowski у 2017 році, зазна- 
чили, що якість політики позитивно пов'язана з булінгом, оскільки школи чи райони $з$ якісною антибулінговою політикою мали білыш високі показники жорстокості або відповідних знущань, ніж школи чи райони із низькою якістю політики. У систематичному огляді емпіричного дослідження Hall у 2017 році було виявлено більше несуттєві, ніж значні, асоціації між присутністю або якістю політики та булінгом серед студентів. Отже, він стверджує, що, незважаючи на широке застосування антибулінгових політик і законів, дослідження, які вивчають зв'язок між якістю законів та рівнем булінгу в закладах освіти, є рідкісними та мають неоднозначні результати. Окрім того, у 2019 році Gaffney визначив, що ефективність програм проти знущань може змінюватися залежно від культури та регіональної реалізації [18].

У різних штатах, залежно від антибулінгових законів, санкщії за булінг можуть передбачати дисциплінарну відповідальність, тобто втручання в навчальний процес через затримання після школи, відсторонення або відрахування (штат Флорида) та кримінальну відповідальність за злочини і деякі проступки (штат Міссурі). Дисциплінарна відповідальність реалізується через кодекси поведінки учнів, розроблені шкільними округами та окремими школами. Політика проти кібербулінгу різниться не лише в штатах, але й в окремих школах у межах одного штату.

При кібербулінгу однією з багаторічних юридичних проблем у США серед освітян є контроль за дотриманням правил поведінки та мовлення студентів, що знаходиться далеко від кампусу. Загалом суди США орієнтовані на підтримку Першої Поправки «прав на вільне самовираження» студентів. Однак, не збігаються з нею певні вирази, саме такі, що істотно або суттєво порушують навчання; утручаються в навчальний процес чи шкільну дисципліну; використовують шкільну технологію для цькування; погрожують іншим студентам або зазіхають на їхні громадянські права. Здебільшого суди підтримують дії шкільних адміністрацій щодо контролю за дотриманням правил учнівської поведінки в інтернеті поза

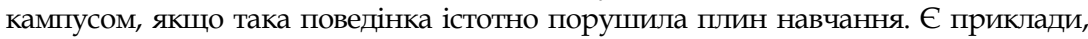
коли школи перевищували свої повноваження або застосовувався необгрунтований та непродуктивний тиск [20].

Ще однією темою, довкола якої точаться дискусії в наукових та політичних колах США, є підхід нульової толерантності, який був прийнятий багатьма школами після трагедії в Columbine High School та Virginia Tech. Критики політики нульової толерантності погоджуються 3 тим, що діти групи високого ризику протиправної поведінки повинні стикатися з якимись дисциплінарними покараннями, але кардинальні заходи припинення незначних порушень завдають білыше шкоди, ніж користі. У багатьох випадках реакція шкільної адміністрації була перебільшеною та непропорційною щодо передбачуваної загрози. Окрім того, існують расові відмінності серед учнів, які отримують сувору дисципліну відповідальність за булінг. Призупиненню, відрахуванню, кримінальній відповідальності підлягають здебільшого афроамериканщі та латиноамериканщі з низькими доходами. Ця політика не враховує індивідуальних обставин порушень, накладаючи однаково сувору дисциплінарну відповідальність на всіх учнів, які порушили правила школи. У 2001 році Американська асоціація адвокатів проголосувала за скасування законів про нульову толерантність у школах, у зв' язку з недостатньою ефективністю цих політик та їх дискримінаційне застосування. Однак, майже 90 \% державних шкіл США мають певну форму політики нульової толерантності [12, с. 384]. 
Наприклад, закон штату Луїзіана 2001 року «Lacts Act, HB 364, Act 230» вимагає від місцевих шкільних рад схвалювати політику, яка забороняє домагання, залякування та знущання з учнів та захист учнів та службовців, які повідомляють про такі випадки. Уповноважує місцеві шкільні ради схвалювати політику нульової толерантності до боротьби в школах та вимагає від учнів, висланих за боротьбу, платити за відвідування уроків та вирішення конфліктів з батьками [21].

У США, на відміну від України, $є$ багатошарова система протидії булінгу, яка складається з державного впливу на освітню систему та регіональних антибулінгових політик, окрім того, є велика кількість громадських організацій, які здійснюють моніторинг, контроль, просування законодавчих ініціатив, профілактику булінгу, реабілітацію жертв або соціалізацію і патронат булерів. $Є$ певні стандартні вимоги щодо антибулінгових законів, які можна враховувати в разі ухвалення Україною законів щодо протидії булінгу. Наприклад, Закон України «Про внесення змін до деяких законодавчих актів України щодо протидії булінгу (цькуванню)» не має жодних рекомендацій чи інструкції щодо антибулінгової політики, яку мають здійснювати заклади освіти, оскільки закон не передбачає освіту фахівців щодо профілактики булінгу та реагування на його прояви. Тобто, хоча зазначений закон покладає на учасників освітнього процесу обов' язки здійснювати антибулінгову політику та дотримуватись їі вимог, контролювати їі належне виконання, але все ж має формальний характер, бо не містить самого механізму боротьби з булінгом. Американські закони мають невичерпні переліки дій, які можна інтерпретувати як булінг і кібербулінг. В Україні ж кодифікованого визначення кібербулінгу взагалі немає, а «булінг» використовується в широкому значенні, не конкретизуючи деякі складові, тому кожен самостійно інтерпретує його. У безпосередньому визначенні булінгу, який доповнює Кодекс України про адміністративні правопорушення, немає ознаки системності, але в Законі України «Про освіту» така ознака з' являється. Зазначене свідчить про недосконалість вітчизняного антибулінгового законодавства і необхідність його покращення з урахуванням зарубіжного досвіду.

Висновки. Незважаючи на щоразу зростаючий інтерес до теми шкільного цькування впродовж останніх 30 років, наразі не існує єдиної думки щодо протидії йому. У США, як і в Україні, не існує інструментів, які дозволяють провести оцінку ефективності впливу розроблених стратегій протидії булінгу, що зумовлює потребу в проведенні подальших досліджень у зазначеному напрямі. Відсутність легального визначення кібербулінгу та деяких інших видів булінгу ускладнює виконання поставлених завдань 3 профілактики цькування в закладах освіти. Тож, ураховуючи зарубіжний досвід, варто боротися не з окремими фактами булінгу, а законодавчо закріпити систему протидії цькуванню в закладах освіти, яка матиме превентивний характер.

\section{Використані джерела:}

1. Melissa Diliberti, Michael Jackson, Samuel Correa, Zoe Padgett, American Institutes for Research. National Center for Education Statistics. July 25, 2019. URL: https:// nces.ed.gov/ pubsearch/pubsinfo.asp?pubid=2019061.

2. Table 1 . Percentage of students ages 12 through 18 who reported being bullied at school, by bullying components and selected student characteristics: School year 2016-17 URL: https://nces.ed.gov/surveys/ssocs/tables/SCS_2017_Standalone_Table_01.asp?referrer=css. 
3. Table3. Among students ages 12 through 18 who reported being bullied at school, percentage reporting each type of bullying, by bullying components: School year 2016-17URL: https:// nces.ed.gov/surveys/ssocs/tables/ SCS_2017_Standalone_Table_03.asp?referrer=css.

4. Christina Yanez, Melissa Seldin, and Rebecca Mann of Synergy Enterprises. Electronic Bullying: Online and by Text. Inc. National Center for Education Statistics. November 19, 2019. URL: https://nces.ed.gov/datapoints/2020042.asp.

5. Justin W. Patchin. School Bullying Rates Increase by 35\% from 2016 to 2019 . Cyberbullying Research Center. May 29, 2019. URL: https://cyberbullying.org/school-bullying-rates-increase-by35-from-2016-to-2019.

6. Cyberbullying Statistics. URL: https://criminal.findlaw.com/criminal-charges/ cyberbul lying-statistics.html.

7. Sameer Hinduja, Justin W. Patchin. State Bullying Laws. November 2018. URL: https://cyberbullying.org/bullying-laws.

8. Brenda High. Making the grade. How States are "Graded" on their Anti Bullying Laws. URL: http:/ / www.bullypolice.org/grade.html.

9. Key Components in State Anti-Bullying Laws, Policies and Regulations. URL: https:// www.stopbullying.gov/ resources/laws/key-components.

10. Florida Statutes Title XLVIII. K-20 Education Code $§ 1006.147$. Bullying and harassment prohibited. URL: https://codes.findlaw.com/fl/title-xlviii-k20-education-code/fl-st-sect-1006147.html.

11. New Jersey A ++. URL:http://www.bullypolice.org/nj_law.html.

12. Laura L. Finley. Encyclopedia of school crime and violence. 2011. URL: https:/epdf.pub/ encyclopedia-of-school-crime-and-violence.html.

13. California Code, Education Code - EDC § 48900. URL: https:/ / codes.findlaw. com/ ca/ education-code/edc-sect-48900.html.

14. Cyberbullying Laws. URL: https://criminal.findlaw.com/criminal-charges/cyberbullying.html.

15. California B. URL: http://www.bullypolice.org/ca_law.html.

16. Missouri Revised Statutes Title XI. Education and Libraries $§ 160.775$. Antibullying policy required-definition-requirements-cyberbullying. URL: https://codes.findlaw.com/ mo/title-xi-education-and-libraries/mo-rev-st-160-775.html

17. Missouri A-. URL:http://www.bullypolice.org/mo_law.html.

18. Stickl Haugen, J., Sutter, C.C., Tinstman Jones, J.L. et al. School District Anti-Bullying Policies: a State-Wide Content Analysis. Int Journal of Bullying Prevention. 2019. URL: https:// doi.org/10.1007/s42380-019-00055-1.

19. Cyberbullying and Social Media. URL: https://education.findlaw.com/studentconduct-and-discipline/cyberbullying-and-social-media.html.

20. Sameer Hinduja, Justin W. Patchin. Cyberbullying Legislation and Case Law Implications for School Policy and Practice. Cyberbullying Research Center. Updated: January 2015. Created: July 2008. URL: https://cyberbullying.org/bullying-laws.

21. Judy Kuczynski. Louisiana C. House Bill No. 364 URL:http:// www.bullypolice. org/la_law.html.

\section{References:}

1. Melissa Diliberti, Michael Jackson, Samuel Correa, Zoe Padgett. (2019) American Institutes for Research. National Center for Education Statistics. July 25, 2019. N. p. URL: https://nces.ed.gov/pubsearch/pubsinfo.asp?pubid=2019061. [in English]. 
2. Table1. Percentage of students ages 12 through 18 who reported being bullied at school, by bullying components and selected student characteristics: School year 2016-17. (2016) URL: https:// nces.ed.gov/surveys/ssocs/tables/ SCS_2017_Standalone_Table_01.asp?referrer=css. [in English].

3. Table3. Among students ages 12 through 18 who reported being bullied at school, percentage reporting each type of bullying, by bullying components: School year 2016-17. (2016) URL: https:/ / nces.ed.gov/surveys/ssocs/tables/SCS_2017_Standalone_Table_03.asp?referrer=css. [in English].

4. Christina Yanez, Melissa Seldin, \& Rebecca Mann of Synergy Enterprises. (2019) Electronic Bullying: Online and by Text. Inc. National Center for Education Statistics. November 19, 2019. N. p. URL: https://nces.ed.gov/datapoints/2020042.asp. [in English].

5. Justin, W. (2019) Patchin. School Bullying Rates Increase by 35\% from 2016 to 2019. Cyberbullying Research Center. May 29, 2019. N. p. URL: https:// cyberbullying. org/ school-bullying-rates-increase-by-35-from-2016-to-2019. [in English].

6. Cyberbullying Statistics. N. p. N. d. URL: https://criminal.findlaw.com/criminalcharges/cyberbullying-statistics.html. [in English].

7. Sameer Hinduja, Justin, W. (2018) Patchin. State Bullying Laws. November 2018. N. p. URL: https://cyberbullying.org/bullying-laws. [in English].

8. Brenda High. Making the grade. How States are "Graded" on their Anti Bullying Laws. N. d. URL: http://www.bullypolice.org/grade.html. [in English].

9. Key Components in State Anti-Bullying Laws, Policies and Regulations. URL: https://www.stopbullying.gov/ resources/laws/key-components. [in English].

10. Florida Statutes Title XLVIII. K-20 Education Code $\S 1006.147$. Bullying and harassment prohibited. N. d. N. p. URL: https://codes.findlaw.com/fl/title-xlviii-k20-educationcode/fl-st-sect-1006-147.html. [in English].

11. New Jersey A ++. N. d. N. p. URL:http://www.bullypolice.org/nj_law.html. [in English].

12. Laura, L. (2011) Finley. Encyclopedia of school crime and violence. 2011. N. p. URL: https://epdf.pub/encyclopedia-of-school-crime-and-violence.html. [in English].

13. California Code, Education Code - EDC § 48900. N. d. N. p. URL: https:// codes. findlaw.com/ca/education-code/edc-sect-48900.html. [in English].

14. Cyberbullying Laws. N. d. N. p. URL: https://criminal.findlaw.com/criminalcharges/ cyber-bullying.html. [in English].

15. California, B. N. d. N. p.URL: http://www.bullypolice.org/ca_law.html. [in English].

16. Missouri Revised Statutes Title XI. Education and Libraries § 160.775. Antibullying policy required-definition-requirements-cyberbullying. N. d. N. p. URL: https://codes. findlaw. $\mathrm{com} / \mathrm{mo} /$ title-xi-education-and-libraries/mo-rev-st-160-775.html.

17. Missouri A-. N. d. N. p. URL: http://www.bullypolice.org/mo_law.html. [in English].

18. Stickl Haugen, J., Sutter, C. C., Tinstman Jones, J. L. et al. (2019) School District AntiBullying Policies: a State-Wide Content Analysis. Int Journal of Bullying Prevention. URL: https://doi.org/10.1007/s42380-019-00055-1. [in English].

19. Cyberbullying and Social Media. N. d. N. p. URL: https:// education. findlaw. com/student-conduct-and-discipline/ cyberbullying-and-social-media.html. [in English].

20. Sameer Hinduja, Justin W. (2008) Patchin. Cyberbullying Legislation and Case Law Implications for School Policy and Practice. Cyberbullying Research Center. Updated: January, 2015. Created: July 2008. URL: https:/ / cyberbullying.org/bullying-laws. [in English].

21. Judy Kuczynski. Louisiana C. House Bill No. 364. N. d. N. p. URL: http:// www.bullypolice.org/la_law.html. [in English]. 
Ведерникова А. А., адьюнкт Луганского государственного университета внутренних дел имени Э. А. Дидоренко

(г. Северодонецк, Украина)

\title{
АМЕРИКАНСКИЙ ОПЫТ УГОЛОВНО-ПРАВОВОГО РЕГУЛИРОВАНИЯ БУЛЛИНГА
}

\begin{abstract}
Проблема насилия в учебных заведениях существует во всех странах мира, но не все принимают меры противодействия этому явлению и проводят политику против буллинга. Америка одна из стран, которая активно борется с буллингом в школе, и ее опыт является бесценным для Украины. В статье анализируются статистические показатели проявлений буллинга и кибербуллинга в США. Раскрыты особенности антибуллиинговой политики различных штатов США, приведены общие положения. Определены современные тенденции и препятствия борьбыс травлей. Предложена имплементация отдельных положений в национальное законодательство Украины.

Ключевые слова: буллинг, травля, дискриминация, анти-буллиннговое законодательство США, анти-буллинговая политика, кибербуллинг, харассмент, нулевая толерантность.

Vedernikova A., Adjunct of Lugansk State University of Internal Affairs named after E. Didorenko (Sievierodonetsk, Ukraine)
\end{abstract}

\section{AMERICAN EXPERIENCE IN CRIMINAL REGULATION OF BULLYING}

The prevention of bullying at school has long been a subject of legislative regulation in foreign countries including the United States. Evaluation of such experience is important for legal science. Researches of bullying in the scientific literature are mainly carried out by specialists in pedagogy, sociology and psychology. Studying of a sufficiently long legislative experience in the United States helps to understand the level of the problem and the probable ways of the normative adjusting. The attitude of combating bullying is different in each state which allows us to consider different approaches of solving this problem. The article analyzes official data provided by the National Center for Education Statistics of the United States and the Bureau of Statistics of the US Department regarding the manifestations of bullying and compares the data connected with bullying and cyberbullying during 2016 and 2019 which are given by the Cyberbullying Research Center. Not a single U.S. federal law specifically concerns bullying but each state has legislation that regulates this issue. Public observant organization "Bully Police USA" deals with the assessment of the quality and effectiveness of the adopted laws as well as changes to them and brings forward 12 demands to them. The article highlights the features of the anti-bullying policy of various US states (Florida, New Jersey, California, Missouri) and provides general provisions. In different states, depending on anti-bullying laws, penalties for bullying may include disciplinary actions such as interfering into learning through post-school detention, removal or expulsion (Florida), and criminal liability for crimes and certain misconduct (Missouri). Today there are no consistent conclusions regarding the content of anti-bullying policies and spreading 
of bullying. The article presents various views on the students' "right to freedom of self-expression" and the policy of zero tolerance. The implementation of certain provisions of the US antibullying laws into national legislation of Ukraine is offered.

Keywords: bullying, discrimination, US anti-bullying legislation, anti-bullying law and policy, cyberbullying, harassment, sanctions, zero tolerance.

DOI: 10.33766/2524-0323.90.102-109

УДК 343.136:343.18

М. С. Городецька,

кандидат юридичних наук, доцент кафедри кримінально-правових дисциплін

та судових експертиз

Донецького юридичного інституту МВС України

(м. Кривий Ріг, Україна)

e-mail: loskutovagorodetskaya@gmail.com

iDhttps://orcid.org/0000-0002-3228-6299

\section{ЗАБЕЗПЕЧЕННЯ ПРОЦЕСУАЛЬНОЇ ДІСДАТНОСТІ СУБ'ЄКТІВ ПРОВАДЖЕННЯ ЯК ОДИН ІЗ АСПЕКТІВ ФУНКЩОНАЛЬНОГО ПРИЗНАЧЕННЯ ПРЕДМЕТУ ВІДАННЯ В КРИМІНАЛЬНОМУ ПРОЦЕСІ}

У статті розглядається забезпечення процесуальної дієздатності суб'єктів провадження як один із аспектів функціонального призначення предмету відання в кримінальному процесі. Проаналізовано, що одним із функціональних призначень предмету відання в кримінальному процесі $є$ набуття законних підстав для створення певного органу кримінального судочинства та законних підстав до здійснення ним певної кримінальної процесуальної діяльності. На підставі аналізу теоретичних уявлень зроблено висновок про те, що в кримінальному процесі щодо суб'єктів, які ведуть кримінальний процес, можна мовити про юрисдикційний режим, що являє собою нормативний комплекс, котрим встановлено предмет відання суб'єкта за предметним, територіальним, темпоральним (часовим), персональним та іншими критеріями.

Ключові слова: підслідність, підсудність, предмет відання, юрисдикція, суб'єкт кримінального провадження, учасники кримінального процесу.

Постановка проблеми. Кожне поняття кримінального процесу виконує певну функцію. Предмет відання не є винятком. У контексті дослідження в кримінальному процесі необхідно визначити його функціональне призначення, тобто відповісти на питання: навіщо потрібен даний елемент, на що він впливає та до яких результатів призводить його реалізація? Визначення функціонального призначення дозволить оцінити, чи відповідає нормативно-правове регулювання функціям предмету відання в кримінальному процесі.

Аналіз останніх досліджень і публікацій. Окремі аспекти функціонального призначення предмету відання в кримінальному провадженні досліджували такі вчені, як: Ю. М. Грошевий, В. С. Зеленецький, О. В. Капліна, Л. М. Лобойко, С. В. Оверчук, А. А. Омаров, М. А. Погорецький, О. Ю. Татаров, В. І. Шишкін та інші. Проте увага вче-

(C) Городецька М. С., 2020 